\section{A crítica}

niekzscheana

da subjetividade'

\section{RESUMO}

O ensaio destaca a ruptura com os conceitos modernos de sujeito e indivíduo que, defende, põe em ação o pensamento nietzscheano. 0 filósofo não somente consagra o primado do corpo sobre a mente mas o do gregarismo vital sobre 0 individualismo ocidental. 0 resultado é a geração de uma nova visão de mundo, na qual o social passa a ser visto a partir do cosmos em sua totalidade.

\section{ABSTRACT}

Michel Haar stresses the significance of the Nietzschean rupture with the modern concepts of subjetc and the individual, showing the way he established the primacy of the body over the mind, as well as that of the collective vitalism over Western individualism. The author thinks the philosopher is committed to the creation of a new world vision, according to which the social point of view, which prevailed until then, is subsumed into a cosmic vision of Being.

\section{PALAVRAS-CHAVE (KEY WORDS)}

- Interpretação (Interpretation)

- Subjetividade (Subjectivity)

- Filosofia contemporânea (Contemporary philosophy)

\section{Michel Haar}

Filósofo, Professor da Universidade Paris I
"A consciência de si é uma ficção" (VPI: 258)

"O eu subjuga e assassina" (VPII: 384)

"O supremo amor para com o eu é correlato ao prazer com a perda de si..."(Ser e tempo)

Que O EU (entendamos por tal a consciência individual) não forma o centro ou o núcleo do sujeito, nem o princípio que determina o pensamento; que o eu não possa servir de fundamento ao sistema de conhecimento; que, ao contrário, ele se descubra sempre e já inextrincavelmente fundido às coisas, ao mundo e aos outros egos; enfim, que o eu reflexivo, que pretende chegar à universalidade, à independência, ao senhorio e à certeza de si não é senão uma construção metafísica, frágil e ilusória: eis um dos temas que, depois de Freud, Heidegger ou Merleau-Ponty, são familiares e como que "evidentes" à nossa Modernidade. Depois da psicanálise, nós não cremos mais na autonomia do eu, essa pobre coisa "esmagada" entre as exigências contraditórias do inconsciente e do superego. Heidegger nos ensinou, entre outras coisas, que o que é "próprio" não nos chega inicialmente senão sobre a forma abstrata de uma "possessividade" (Jemeinigkeit) impessoal e que, como tal, ele jamais é adquirido através das primeiras palavras ou dos primeiros gestos, totalmente prisioneiros das maneiras do "se" impessoal. Nós sabemos que em relação ao ser no mundo e ao cuidado essa grife da temporalidade - o eu não é uma estrutura fundamental do ser humano. $\mathrm{O}$ eu pode ser entendido, por exemplo, como um efeito lingüístico do cuidado: "com o eu o cuidado se exprime inicialmente e na maioria das vezes no dizer eu da preocupação". Nós sabemos também que Merleau-Ponty reabilitou a abertura anônima da percepção, essa coação silenciosa onde ainda não há nenhum sujeito, mas onde cada eu fixa suas raízes pré-individuais e compartilha com todos os outros uma afinidade mais profunda que a da simples "luta das consciências", sempre posterior.

Ora é pouco assinalado que em suas análises da subjetividade, Nietzsche não 
apenas pertence totalmente a essa modernidade mas além disso a ultrapassou em diversos aspectos. Aparentemente fascinado seja pela fachada mais ontológica que psicológica da vontade de potência, seja pela problemática da má consciência ou do ressentimento, Heidegger como primeiro comentador de Nietzsche, está pouco interessado na sua teoria do sujeito e na dimensão crítica que ela carrega. ${ }^{2}$ Em Heidegger, em particular, o desprezo pela psicologia de Nietzsche é tão grande quanto o seu interesse pelo "último metafísico", este que conduziu a metafísica pós-cartesiana da subjetividade a seu acabamento absoluto. Nietzsche teria trazido ao sujeito hegeliano "ainda inacabado" o complemento necessário para elevá-lo à "subjetividade finalmente acabada" (Nietzsche II: 241), uma espécie de animalidade absoluta, muito mais que racionalidade. Esta interpretação oculta todas as objeções tanto quanto as mutações que Nietzsche introduz no conceito clássico de sujeito.

Aliás, proviriam as análises nietzscheanas da psicologia ao invés da filosofia pura? Chamando a si mesmo antes de mais nada psicólogo, o próprio Nietzsche sem nenhuma dúvida embaralhou as pistas. Aforismos como os seguintes: "não existem mônadas" (KGW VIII 2, 11[73]); "o homem, pluralidade de vontade de potência" (VP I: 258); "nós somos uma multiplicidade que construiu para si uma unidade imaginária" (VP I: 255) - são todas proposições incontestavelmente metafísicas, que recolocam de maneira direta o problema da unidade transcendental do sujeito tanto quanto o da relação entre um e o múltiplo no seio da subjetividade.

[ $\mathrm{Na}$ verdade] $\mathrm{O}$ ponto exato sobre o qual Nietzsche ataca e tenta reverter a doutrina tradicional do sujeito não é outro que o da idéia de uma essência lógica do eu. Ora, essa idéia se encontra na base das teses metafísicas de Descartes e de Kant sobre o ego, teses às quais Nietzsche se prende de maneira explícita. Para o racionalismo, que se preocupa acima de tudo com o fundamento do conhecimento, o eu não pode se definir como necessário e universal senão à medida que se identifica com o poder lógico do sujeito. Em Descartes, o eu está restrito e se identifica com o entendimento ou a razão: "Falando de maneira precisa, eu não sou, portanto, senão uma coisa que pensa; quer dizer, um espírito, um entendimento ou uma razão". ${ }^{3} \mathrm{Em}$ Kant, "o princípio da unidade sintética da apercepção" ou, em termos menos escolares, o poder unificador da consciência "é o princípio supremo de todo o uso do entendimento". ${ }^{4}$ Isso quer dizer que a unidade do eu é a condição primeira do fundamento mesmo da nossa faculdade lógica. A unidade do eu torna possível a unidade do conceito, a própria operação da conceitualização. O eu é a unidade primordial, arquetípica: "Para o eu, diz Kant,... não há nenhuma diversidade" (ibidem). Ao contrário, "a unidade originalmente sintética da apercepção", quer dizer: a consciência transcendental não é apenas "o ponto mais elevado" ao qual é preciso voltar toda lógica, mas "é esse poder [unitário] o próprio entendimento (ja dieses Vermögen ist der Verstand selbst). Portanto é preciso dizer não que o eu puro condiciona o entendimento, mas que ele é o entendimento. Desta identidade do eu e do entendimento, Kant não fornece nenhuma prova que não negativa, ou através de uma fórmula absurda: "Sem isso, eu teria um eu muito diverso e teria tantas cores quanto existem representações do que eu tenho consciência" (ibidem). A essência do eu é de um ser único, idêntico a si mesmo, não contraditório, quer dizer: lógico, de modo que o "eu" se revela a própria lógica!

Ora a crítica Nietzscheana do eu passa em primeiro lugar por uma crítica da lógica, sobre a qual repousam as doutrinas racionalistas do eu. "A crença no eu se sustenta e se desmancha ao mesmo tempo que a crença na lógica" (WM § 519). A crença comum nessas duas crenças é a crença na existência de identidades estáveis. Significa que, para Nietzsche, isso equivale à crença 
platônica no ser, àquilo que é igual a si mesmo. Por que crença? Porque a experiência não fornece nenhum dado que seja estritamente idêntico, estritamente único em si mesmo. Nada no mundo, no real, é apenas um. Portanto o um é imaginário, irreal, fictício. "A lógica está ligada a essa hipótese: a suposição que há casos idênticos" (VP I: 73). Que a identidade seja fictícia não significa, porém, que ela seja vã ou ilegítima. A lógica não se regula sobre os fatos, mas impõe certos esquemas semelhantes aos de uma ficção reguladora, que permite responder às necessidades práticas (previsões, cálculos, planos de ação) e de dominar a realidade. A lógica é imposta por uma vontade que tem a necessidade de que as coisas sejam idênticas e de que exista uma unidade, para sua própria seguridade. Ora o eu é tal unidade, ao mesmo tempo útil e fictícia. A importância da crença no eu é fundamental para a lógica, na medida em que os conceitos de "substância", de "coisa", de "causa" e de "efeito" e, finalmente, aqueles de "realidade" e de "ser" são deduzidos de nosso conceito de "sujeito". Nós não cremos na identidade porque nós tenhamos "em nós" o modelo de toda identidade possível: o eu. Todavia, a crítica desse conceito de "sujeito" e de suas "faculdades" deveria engendrar a ruína do sistema metafísico de categorias, totalmente derivado das propriedades atribuídas ao sujeito. Em outros termos, as crenças lógicas, isto é, que a substância subsiste como o eu, que a causa produz seu efeito assim como o eu produz seus atos, se desmanchariam se fosse demonstrado que a figura do eu não se sustenta, que ele não é a causa única de seus atos.

Mas por que destruir essas ficções lógicas sendo elas úteis? Nietzsche deseja reduzir a lógica a uma simples função instrumental, operatória. A justificativa de sua crítica é a confusão estabelecida correntemente entre as "identidades lógicas" e os princípios da própria realidade. A ilusão transcendental da lógica consiste em sempre projetar novamente no ser em si mes- mo as unidades lógicas. Desse modo, a crítica à unidade do eu, o despedaçamento, a pluralização do eu teriam por finalidade última confessa recuperar a pluralidade do ser, "os graus do ser", como ele diz, por exemplo, nos fragmentos abaixo: "O conceito de substância, conseqüência do conceito de sujeito, e não o inverso! Se nós renunciamos à alma, ao "sujeito", a condição prévia de uma substância desaparece totalmente. Há graus no ser, nós perdemos o ser" (VP I: 82).

"Renunciar à alma, ao sujeito" significa em primeiro lugar renunciar à universalidade abstrata desses conceitos e afirmar a individualidade do eu. Não há eu senão individualmente. Como o confessa implicitamente Descartes (mais prudente nisso do que Kant): “Eu sou um entendimento, uma razão; e não o entendimento em geral, a razão". Mas num segundo momento, significa renunciar ao sujeito; quer dizer: é reconhecer que o indivíduo não é um, que a unidade individual é fictícia; é recuperar a pluralidade intra-individual. Trata-se não tanto de repensar mas sim de reaprender a experimentar essa pluralidade. Uma vez rompida a unidade lógica do sujeito e sua unidade moral, a "pessoa", "outra máscara a arrancar", será preciso deixar agir as potências múltiplas do eu, todos seus papéis, seus diversos estados corporais e anímicos. Aqui o ideal do filósofo-Versucher, experimentador, se insinua insensivelmente na descrição quase fenomenológica do eu múltiplo. A finalidade é em primeiro lugar experimentar a plenitude da subjetividade e, a experimentando, a recriar, se interrogando sobre sua verdadeira essência. O homem mais humano será capaz de passar por diversos ideais, diferentes personagens ou papéis, "ver por cem olhos, através de diversas pessoas" (VP II: 82).

Tendo-se dado conta da leitura heideggeriana, a questão que se coloca a partir de então é saber se Nietzsche logrou realizar um "acabamento da subjetividade". É muito cedo para arriscar uma resposta. Tudo o que se pode dizer é que a plenitu- 
de do sujeito individual vista por Nietzsche, plenitude transitória, não tem nada a ver com a totalização "conservadora" de momentos ultrapassados, que caracteriza o sujeito universal em Hegel. A autenticidade nietzscheana, se se ousa utilizar esse termo, se situa do lado oposto à da autenticidade heideggeriana. Para Heidegger, a diversidade das preocupações cotidianas, com as interpretações estabelecidas pelo ser, é necessariamente "má", ao menos alienante: o ser aí é ameaçado de decair na "curiosidade" ou na "preocupação"; o homem para ser homem deve corresponder à doação simples que lhe dirige o Ser. Para Nietzsche, ao invés, o eu não se encontra senão quando nos esquecemos de nós como pseudo-unidade, quando nos prendemos à ronda dos papéis e das perspectivas. Em termos nietzscheanos, o movimento mais autentico, o mais afirmativo e o mais arriscado comanda a maior diferenciação do eu, e não mais a sua maior simplificação. $\mathrm{O}$ "espirito livre" é definido como aquele que sabe evitar o aprisionamento de suas crenças ou de suas certezas "pelas suas constantes variações", até o ponto de parecer "uma massa de nuvens pensante" (WM, § 637)! Para realizar o ideal do "viajante" em Humano, demasiado humano, Nietzsche defende que é preciso progredir "através da variedade dos partidos, traindo nobremente todas as coisas ..."(ibidem). "Nobres", tudo está aí: não é de fato preciso muita nobreza, quer dizer: de afirmação generosa e rigorosa, para atravessar essa variedade sem dissolver o eu na inconstância e na frivolidade?

A experimentação das "variedades do eu", como dirá Valéry (Cahiers I, p. 861), não fecha a individualidade sobre ela mesma, mas a realça e a transporta para fora de si e para dentro do mundo. O eu capaz de apreender e de viver a diversidade das condições e das filosofias é o mais apto também a sentir o "laço cósmico"; isto é, não somente a se sentir inseparavelmente ligado a toda a linha dos seres vivos e a toda a ascendência histórica, mas a enten- der que ele faz parte do fatum universal, que ele é esse fatum. Ego factum: "Todo o indivíduo colabora no conjunto do ser cósmico - conscientemente ou não, de bom ou mal grado" (VP II: 384). "O indivíduo é sempre um fragmento de fatum, qualquer que seja o ângulo que o consideremos" (GD 6). Entretanto, o eu cósmico deve ser compreendido como uma etapa preparatória do amor fati, da afirmação do eterno retorno? A subjetividade não é abolida nessa forma extrema, e talvez impensável, de fatalismo? Toda a crítica da subjetividade não tem por motivo último senão cair numa afirmação pânica que põe em eclipse todo o ego?

Quebrar a identidade lógica do sujeito, recuperar a pluralidade intra-individual, desenvolver a dimensão cósmica do eu: é certo que essas tarefas da crítica não são marcadas pela preocupação especulativa do "conhecimento de si", mas por uma preocupação prática, surpreendentemente ambiciosa, que consiste em modificar a própria essência da subjetividade.

\section{Quebrar a identidade lógica do sujeito}

"A consciência de si é uma ficção" (VPI, p. 258). “Não há nem espírito, nem razão, nem pensamento, nem consciência, nem alma, nem vontade, nem verdade: tudo isso não passa de ficções inutilizáveis" (WM § 480). Precisamente o que quer dizer aqui ficção? Ilusões certamente, mas também "invenção poética", "sonho de poeta", porque Nietzsche emprega freqüentemente, no lugar de Fiktion, os termos Eradichtheit, Eradichtung ou, pura e simplesmente, Dichtung. Ainda que sem pôr em causa a posição nietzscheana, que faz com que as categorias lógicas das unidades ilusórias se projetem sobre a multiplicidade do real, uma objeção se apresenta muito naturalmente. Como Nietzsche pode ao mesmo tempo conferir um sentido pejorativo à ficção lógica e conceder à ilusão poética, como a arte em geral, 
o valor mais alto? Esta aparente contradição se resolve se nós nos recusarmos a nos referir ao que é dito da poesia, e em particular no capítulo do Zaratustra intitulado Os poetas. "Os poetas mentem muito." Nós sublinhamos a palavra muito, porque tudo está nesse "muito". A mentira poética não vale senão se escapa à pretensão de ser uma substituta da verdade. Os poetas mentem demasiadamente, quando eles esquecem que eles mentem, quando eles pretendem dizer a verdade em si mesma, por revelação direta. Somente a ficção que sabe ser tal é bemfeitora; senão, ela é uma espécie de automistificação. "O poeta que sabe mentir com conhecimento de causa, voluntariamente, é aquele que pode dizer a verdade" (Gedichte, KTA 77, p. 574). Existe em Nietzsche uma apologia da mentira franca, como é o caso da arte. Os filósofos, os lógicos, ao contrário, estão muito longe de pensar produzir ficções. Eles são mentirosos mistificadores: sua mistificação consiste em querer fazer crer que suas categorias, suas "viagens poéticas", exprimem a essência mesma das coisas.

Sempre guardando como ponto de partida a definição platônica da verdade como sendo o um, o idêntico e o não-contraditório, Nietzsche não pode, em sua reversão do platonismo, escrever sua própria definição da "verdade" (a mentira não dissimulada, reconhecida como tal) que, por assim dizer, entre aspas! Para ele, o "verdadeiro" está do lado do múltiplo e da contradição. A "aparência" ou a "ilusão" estão no lugar do único e da identidade.

Desse modo sua própria "verdade" não é uma verdade que o homem possa conhecer, mesmo inadequadamente, porque conhecer consiste em transplantar o múltiplo para o único, e portanto a negar o múltiplo. Assim, não é tanto a característica fictícia do sujeito que Nietzsche critica mas sim o esquecimento ou a ignorância desse caráter fictício. Crendo em sua própria unidade, o sujeito faz de si mesmo uma imagem mutilada e diluída. “O sujeito é uma multiplicidade que construiu para si mes- mo uma unidade imaginária" (VP I: 255). O perigo não está tanto nessa unidade como tal, mas no efeito de encobrimento e de obstaculização ao desenvolvimento da multiplicidade interna por ela produzida.

É importante mostrar quais são esses efeitos de ocultamento e quais são as relações de dependência entre unidade lógica, consciência e o sujeito "total" ou, em todo caso, não lógico. Fiel nesse ponto à tradição metafísica, Nietzsche não pode com efeito reconhecer à consciência o caráter de um sujeito, na medida em que o sub-jectum, o que se supõe subjacente, deve poder fornecer uma base ou fundamento, ou deve poder receber os atributos os mais diversos. A consciência não pode sustentar, suportar a subjetividade! "Nós chegamos à fase onde a consciência se torna modesta" (VP I : 278). A consciência será reportada à modéstia por meio de seu confronto com as "instâncias" mais complexas e mais poderosas: o corpo, o pensamento não-conceitualizante, os sentimentos, o mundo exterior, a linguagem e a comunicação social.

Acima de tudo, porém, está o corpo. Por que é preciso filosofar "tomando o corpo como fio condutor"? (VP I: 262) Porque é ele que merece ser chamado de sujeito, ou que mereceria tal selo, se esse conceito unificante não arriscasse dissimular a pluralidade que ele abriga: ele é chamado de uma "coletividade não ligada de seres vivos" (VP I : 265), uma competição de "inúmeras inteligências" (VP I: 265), como "um edifício coletivo de diversas almas" (VP I : 267). A unidade da integração viva e inata ao corpo humano é "o milagre dos milagres" ( $A B M, \S 19)$. Em relação a ela "a consciência não é senão um instrumento a mais - no mesmo sentido em que o estômago é um instrumento de milagre idêntico" (ibidem). A coordenação, a coesão, a sabedoria, a seleção, a crítica, a prudência, etc., podem ser compreendidas inicialmente como qualidades do corpo, e não da consciência. A identidade consciente do eu não é senão uma transposição, uma imitação frágil, senão um sintoma da sólida unidade e da co- 
erência fisiológica. Se "o corpo é nosso eu" (VP I: 253), esse eu orgânico não é uma simples unidade conceitual, mas possui uma unidade real, quer dizer múltipla, que é freqüentemente comparável àquela de um grupo, "grupo de dirigentes à frente de uma coletividade" (VP I: 268), uma "aristocracia" de forças habituadas a comandar e a governar um conjunto na condição de "um comitê diretor". É inútil procurar a razão de ser lógica dessa coordenação de "células" e das diversas forças orgânicas, pois a consciência só poderá fazer delas uma interpretação deformada.

Assim ocorre porque a consciência deve se manter ignorante do que se passa no plano do corpo. Ela é comparável - outra metáfora política - a uma monarca constitucional, que reina mas não governa. Ela deve ser mantida à parte, protegida dos conflitos que agitam a "sociedade" das pulsões; se ela devesse ser informada de todas as sensações e de todos os acontecimentos do mundo que no entanto a tocam, ela seria sufocada, anulada. Resumidamente ela deve, por isso, ser protegida do múltiplo, e não ter acesso senão às grandes simplificações que mantêm a ordem e a polícia da realeza. "Uma certa ignorância na qual se mantém o monarca em relação às operações de detalhe, e mesmo dos problemas da coletividade, faz parte das condições que lhe permitem reinar" (ibidem). Esses problemas, que resultam da redistribuição incessante do equilíbrio interno das forças, constituem a face oculta (à consciência) do dinamismo psíquico. Fenômeno superficial, terminal, derivado e inclusive "supérfluo", a consciência algumas vezes é, perigosamente, capaz de se importar, quando ela se emancipa radicalmente dos instintos, ignorando a origem e o sentido mesmo da atividade ("a grande e principal atividade é inconsciente" (VP I : 267).

Faculdade inibidora da ação, a consciência - para perpetuar sua ilusão - deve a cada instante inverter, "como num espelho" (VP I: 279), o desenvolvimento da vida psíquica. Ainda que ela creia dar ordens, ela não faz senão registrar, executar. Ela atribui os diferentes estados psíquicos a uma causa única, que é ela mesma. Ela prejulga a continuidade dessa causa através do tempo. Ela crê inclusive - é a ilusão suprema - que ela é um substrato que "controla" a totalidade do sujeito, determina e guia com tranqüilidade as funções corporais. A substancialização metafísica do eu resultaria assim da vaidade e do cegamento sem limites da consciência, que crê a tudo "supervisionar" e reger e, finalmente, chega até mesmo a crer que comanda os pensamentos.

Entretanto, se de fato a consciência não produz nem a unidade do corpo, nem sua própria unidade, ela está bem longe de poder ser senhora dos pensamentos ( $G e-$ danken). Nietzsche retira o privilégio do pensamento (Denken) da consciência. Não apenas é o corpo que pensa, mas “o pensamento consciente não é senão uma forma grosseira e simplificada desse tipo de pensamento que está necessariamente em nosso organismo" (VP II: 280). O eu é colocado, construído por esse pensamento inconsciente (cf. KGW VII 3, 35). Ele não é o autor do pensamento, pois o pensamento o ultrapassa. A evidência cartesiana do eu consciente como algo consubstancial, "igual ao pensamento", e como causa dos pensamentos se encontra invertida a partir de um duplo ponto de vista. De um lado essa evidência contradiz a experiência que me ensina que os pensamentos chegam a mim quando "eles" querem, e não quando "eu" quero $(A B M, \S 16-17)$. "Eu” não sou o senhor do desdobramento de meus pensamentos: esse se impõe ao eu. De outro lado, a idéia de que o eu é um substrato permanente idêntico ao pensamento implica numerosas pressuposições inverificáveis, como a de "que eu sei o que significa pensar" (ibidem), ou a de que há uma relação de causa e efeito entre o eu e a atividade do pensamento. Ora essa última crença, segundo a qual o eu "produz o pensamento", não é senão um efeito da "rotina gramatical" que identifica o sujeito gramatical 
de um verbo com o autor de uma ação. É a mesma ilusão que existe na frase: "o claro ilumina", que poderia nos conduzir a conferir ao claro uma realidade substancial, independente do fato do iluminar.

O pensamento é, como o corpo, de natureza múltipla, muito antes de ser algo que possa se identificar com o eu. No nível mais superficial, nós lidamos com o pensamento consciente, lógico, simplificador, falsificador, mas ignorante de suas falsificações. Trata-se de um pensamento tautológi$\mathrm{co}$, um pensamento da identidade, fechado sobre ele mesmo, que crê se mover na pura liberdade de sua autoprodução, na pura transparência consigo mesmo. No outro extremo, o pensamento do corpo nos é inacessível diretamente, nós não podemos perceber senão seus sintomas, de modo que, sobre essa matéria, só podemos fazer conjecturas. Por exemplo: certamente há no inconsciente uma simultaneidade de idéias que nos é incompreensível, porque nós não podemos pensar senão por via de sucessão. A única maneira de corresponder a este pensamento é se limitar a esse terreno intermediário que é o terreno da interpretação. A interpretação se apóia nos pensamentos tais como eles nos vêm a mente, permanecendo atenta a seu lugar sintomático juntamente com os sentimentos e os instintos (cf. GC § 179), mas deve-se saber também que toda interpretação é redutora e falsificadora na medida em que é consciente. Nenhum desses três graus do pensamento que são a consciência, o inconsciente e a interpretação se deixam iniciar pelo eu. A descrição surpreendente que Nietzsche dá do nascimento de um pensamento em um sujeito insiste sobretudo sobre a passividade do eu, "muito mais um espectador do que um criador desse processo".

“O pensamento (Gedanke), tal como acontece, é um signo plurívoco que exige uma interpretação, mais exatamente um recolhimento e uma limitação arbitrários, até o ponto em que ele se torne finalmente unívoco. O pensa- mento acontece independentemente de minha vontade, habitualmente cercado e obscurecido por uma multidão de sentimentos, de desejos, de recusas, com relação a outros pensamentos; muito freqüentemente é com dificuldade que se pode distingui-lo de um querer ou de um sentir. Extraímolo desta confusão, limpamo-lo, o colocamos sob seus pés, vemos como ele tem seu início, marcha, como o todo forma um surpreendente presto e, no entanto, sem sentirmos sua rapidez: quem faz tudo isso - eu o ignoro, e nisso tudo seguramente eu sou muito mais um espectador do que um criador do processo." (KGW VIII 3, 38[1])

A interpretação a qual o pensamento (Denken) se conduz não exige a presença de um intérprete "por de trás" da interpretação. Isso ainda seria uma ficção (VP I: 274). A interpretação ocorre muito bem na ausência do eu: ela é "automática". Tudo o que nós podemos dizer é o seguinte: a interpretação interpreta.

A dependência da consciência em relação ao mundo exterior é difícil de avaliar, sobretudo do ponto de vista da consciência, porque a ilusão própria à consciência faz com que ela não conheça o que é esse "mundo exterior", senão sobre a forma de uma construção (o fato, por exemplo, de que esse mundo seja concebido como uma totalidade), um arranjo em função de suas próprias necessidades, e que, por conseguinte, ela seja incapaz de mensurar a extensão das influências que sofre. No entanto é certo que as categorias lógicas não pertencem a uma estrutura autônoma da subjetividade, mas sim que sejam respostas às ameaças provindas do mundo. A invenção dos "casos idênticos", a redução do conhecido ao desconhecido, a casualidade, etc., são também instrumentos de previsão, de seguridade, de dominação que traduzem a potência do perigo pressentido pela consciência, quer dizer: a potência da dominação do mundo sobre essa consciência. Por de 
trás de sua inventividade lógica, a consciência não é senão "um instrumento de transmissão" das ações que por trás de nós e de nossas ações sobre o mundo externo; "ela não é essa transmissão" ... "mas um órgão dessa transmissão", sublinha Nietzsche (VP I : 274). Quanto à sucessão e ao encadeamento dos fenômenos no mundo e dos pensamentos em nós, eles também nos são perfeitamente ocultos e impenetráveis, sendo nisso da mesma forma que, em Kant, os são as coisas em si. Em relação aos mesmos, a consciência sempre dá explicações "imaginárias": "Toda nossa pretendida consciência não é senão um comentário mais ou menos fantasioso de um texto desconhecido" (VP I: 265). O mundo nos é desconhecido. Nós inventamos todas as "causas", "depois de tê-las em mãos": "O fragmento do mundo exterior do qual nós tomamos consciência é posterior ao efeito que foi produzido sobre nós; ele é projetado após ter provocado esse efeito como sendo então a sua causa" (VP I: 272). Desse modo, a consciência - longe de nos ensinar sobre o mundo tal como ele é - não é senão a soma do que nele há de útil para saber. Mas essa visão estreita e deformadora prova até que ponto a consciência é determinada por sua posição no mundo e pelo próprio mundo.

Fazendo a consciência ao mesmo tempo um instrumento e um produto da comunicação social e, ainda, alegando a superficialidade e a abstração da linguagem ao fenômeno da consciência, Nietzsche destaca os prejuízos da consciência em sua ligação com o eu, com a individualidade. "No fundo a consciência não pertence à existência individual do homem..." (GC, § 354). Essa proposição não é senão a consciência da tese seguinte e segundo a qual "o corpo é o nosso eu". A consciência e a linguagem transpõem esse eu em termos não individuais, porque não é de "meu interes-

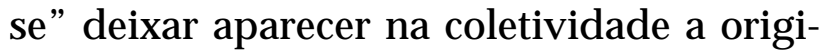
nalidade funcional ou não-lógica dessa individualidade e que, de outro lado, essa individualidade como tal possa não ser útil à coletividade: é preciso que ela seja "retraduzida na perspectiva do rebanho". Por isso Nietzsche pode dizer, numa inversão aparentemente biológica, a propósito da consciência, que ela não é a forma mais alta da idealidade, mas "o gênio da espécie". Ser consciente, experimentar-se em termos de consciência, falar, escrever, não é trabalhar por conta própria mas, por um tipo de astúcia nietzscheana da razão, pelo benefício da espécie humana. Naturalmente é preciso isentar dessa palavra e dessa escrita aquelas que justamente subvertem a essência convencional da linguagem, como acontece na escrita aforística e fragmentária. Mas essa exceção confirma a regra, segundo a qual é graças à linguagem que a consciência persegue ainda e sempre seu trabalho de dissimulação.

\section{Reencontrar a pluralidade intra- subjetiva.}

Se a unidade lógica do sujeito é oculta, como o são as "faculdades" do sujeito (vontade, razão, imaginação, sentimento), isso é assim sobretudo na medida em que cada uma dessas unidades dissimula a pluralidade (de forças, de motivos) que concorre em toda ação e em todo o pensamento. No entanto, seria igualmente ilusório pretender restituir como tal essa pluralidade, pois ela releva do inconsciente; e o simples fato de a transpor para a linguagem significa a transpor em uma unidade. O desdobramento efetivo dos fenômenos psíquicos nos permanece sempre impenetrável, desconhecido. "Nós não temos nenhum órgão sutil o bastante para apreender esse mundo interior, se bem que nós sintamos como uma unidade a complexidade mais multiforme, e que nós introduzamos uma causalidade imaginária em um domínio onde todos os motivos do movimento e da mudança nos permanecem invisíveis..." (VP I: 274). Todavia, restam duas vias abertas à análise. De um lado, a demarcação regressiva que consiste em mostrar a unida- 
de psicológica, qualquer que ela seja (a consciência, as faculdades), como uma unidade superficial, derivada, um "termo derradeiro", uma "conclusão" e, portanto, algo que deve ser reposto a suas condições inaugurais, aos acontecimentos que estão "por trás" dela sem no entanto pretender restabelecer o encadeamento "causal" e original. Será suficiente que o que era considerado como causa apareça claramente como um efeito. De outro lado, a análise fará aparecer uma diversidade de motivos latentes, assim como de motivos concorrentes, entrecruzados e concomitantes. Então, será suficiente poder mostrar a imbricação, a solidariedade absoluta desses motivos, de modo a que todas as divisões das antigas faculdades sejam relativizadas. Desse modo aparecerá que não há afetividade sem intelecto, não há emoções - nem mesmo sensações - que não contenham julgamentos (cf. VP I : 316), que não há nenhuma vontade racional sem emoção.

Porém, é precisamente o conceito de "vontade" que é o objeto privilegiado dessa desconstrução nietzscheana. A "vontade" não é apenas um princípio coerente, uma força simples, uma causa determinada e focalizada que engendra efeitos. A análise revela nesta "unidade puramente verbal" (ABM, § 19) um resultado consciente, que surge da convergência de uma pluralidade composta de sentimentos ou de sensações, de idéias ou de raciocínio, de algo quase como personagens interiores. Afinal de contas, aquele que procede a um ato de vontade deve poder comandar a si próprio, se desdobrar em um mestre e em um executor de alguma coisa. E, deve ser bem entendido, esse ato de comando não se produz em uma atmosfera de serenidade, mas em clima emocional. A "paixão de comandar", com os sentimentos que a acompanham - prazer de se infringir uma coação, prazer de vencer em si mesmo a resistência - não é a causa dos atos voluntários, mas apenas um sintoma correlativo. $\mathrm{O}$ "eu quero" aparece à consciência quando a "hesitação" (o conflito de numerosas tendências) foi suplantada ao nível inconsciente; quer dizer: quando uma certa hierarquia provisória de pulsões se estabelece. A "vontade" não é invocada senão quando nós esperamos poder ter sucesso, quando existe a possibilidade efetiva iminente, ou em vias de se concretizar, de agir; em outros termos, quando nós temos o sentimento de que nós estamos obedecendo a nós mesmos. É impossível de dissociar o sentimento de passagem de um estado dado a outro, como algumas das sensações musculares que o acompanham, de um projeto calculado e refletido de mudança. Mas esse projeto pode ser a racionalização de uma explosão de força ou de uma mudança que precede o projeto. Apenas parece que nosso corpo mudou, que nós "queremos" mudar.

Nietzsche chama os diferentes protagonistas dessa luta interior - que apenas de maneira muito fraca pode ser entendida como um debate - (quer dizer "aquele que comanda", "aquele que obedece", "aquele que sente uma satisfação"), no seio do sujeito que quer de: "sub-vontades" ou "subalmas" (ibidem). De fato trata-se de partes do inconsciente ou do corpo, "um edifício de almas múltiplas" (ibidem). Então por que falar de "almas"? A usurpação ou a inversão que atribui o nome "nobre" de alma ao que a tradição considera como inferior está destinada a designar os verdadeiros "princípios ativos": as pulsões, os instintos. ${ }^{5}$

No entanto, a pluralidade subegótica não se reduz simplesmente às forças do inconsciente corporal, da mesma forma que ela não pode ser assimilada à diversidade dos sentimentos ou das idéias. A identidade lógica do eu, ou a identidade moral da pessoa se estabelece às expensas da presença de múltiplas "pessoas", quer dizer: na maioria das vezes, os papéis que se sucedem ou coexistem no psiquismo individual. Nietzsche não deixa de sublinhar que "a pessoa" não é senão a acentuação, devida às circunstâncias, de múltiplas "pessoas", personagens ou personalidades, que nós carregamos em nós no estado mais ou menos virtual. Mais freqüentemente acon- 
tece que uma persona, quer dizer um personagem dramático, "mascarado", mais ou menos arbitrariamente", nos cola à pele e ocupa um lugar único na cena da consciência, às expensas das máscaras que nós carregamos "no corpo".

"Somos mais ricos do que nós pensamos: carregamos no corpo o estofo de numerosos personagens, carregamos por caráter o que de fato pertence à personagem, a uma de nossas máscaras. A maior parte de nossas ações não nos vem do nosso interior mais profundo, mas é algo superficial, como a maior parte das erupções vulcânicas; é preciso não se deixar levar pelo barulho violento."

"Contemos em nós o esboço de numerosas pessoas: o poeta é traído através de seus personagens. As circunstâncias exigem de nós uma certa figura (Gestalt); quando as circunstâncias mudam muito, cada um descobre em si duas ou três figuras. - A partir de cada instante de nossa vida, há numerosas outras possibilidades: aí o acaso sempre contribui!". (VP I : 264)

"Todo personagem é acima de tudo um papel" (KGW VII 3, 34 [57]): isso significa que o indivíduo não possui um fundo substancial original que vem à luz e que ele é capaz de objetivar, como é o caso, por exemplo, em Hegel. O indivíduo não é uma substância, mas existe, ao entrar constitutivamente em seus papéis. Mas o que é um papel? De onde vêm os papéis? Como eles podem pertencer ao corpo? Um papel não é apenas uma função social totalmente exterior, que exige uma certa conduta predeterminada, mas um acordo íntimo que a sociedade solicita de nós, sob o plano da família, da profissão, das obras... As pulsões "coletivas" interiorizadas pelo indivíduo são muito mais antigas e muito mais poderosas do que as pulsões individuais. Os "papéis" representam as máscaras das pulsões pré-individuais. Enquanto tais, eles não relevam nem do nós nem do eu. $\mathrm{O}$ papel, como sem dúvida o próprio sujeito, não é nem anônimo nem único: é "um efeito do mundo exterior sobre nós, mundo em relação, ao qual nós concedemos nossa 'pessoa' como nós afinamos cordas para tocar" (KGW VII 2, 25[374]). O papel constitui a matriz do indivíduo: ele fornece um texto que não é escrito por um "eu", do qual os outros são os autores mas dos quais meu corpo aprendeu as palavras. Daí a idéia de que o homem é um ator, mas que todo ator tem numerosos papéis:

"Em que medida o homem é um ator. Admitamos que o indivíduo receba um papel para desempenhar: ele se encontra pouco a pouco nele. Finalmente chegam julgamentos, desgostos, as inclinações que correspondem a seu papel, e mesmo o grau de inteligência que com ele se relaciona ordinariamente: - Primeiro a criança, o adolescente, etc., depois o papel ligado à sexualidade, depois aquele que releva a posição social, em seguida o da profissão, em seguida o das obras. Mas que a vida lhe dá ocasião de mudar, ainda que lhe atribua assim um outro papel. Freqüentemente os papéis em um mesmo homem são diferentes de acordo com os dias, por exemplo o inglês durante o domingo e o inglês durante a semana. Em um mesmo dia nós somos muito diferentes, na medida em que nós estamos despertos e que nós dormimos. E no sonho nós repousamos talvez do cansaço que nos dá o papel diurno - e nós nos metemos em outros papéis" (KGW VII 2, 25\{374]).

Os papéis que determinam a psicologia individual cotidiana são impostos a partir do interior. Eles são condições de fato, e portanto eles produzem toda a riqueza da interioridade (julgamentos, gostos, inclinações, inteligência). Ora a consta- 
tação maior que daí decorre é a de que se o acaso das circunstâncias ("a ocasião") oferece ao homem poucos papéis, ele terá uma outra psicologia. Partindo daí, Nietzsche sugere que se passe do fato ao ideal, da mudança sofrida à mudança desejada: não aceitar passivamente os papéis, mas ver como decorrem dos papéis todos os tipos de conduta, pesquisar espontaneamente novos papéis. "Considerar nosso modo de viver e de agir como um papel a jogar compreendidas aí as máximas e os princípios..." (VP I: 263). O homem ativo é aquele que não passa por ator, mas assume o tanto de ator que ele é. Por aí ele reivindica como pertencente a toda a vida a conotação de ilusão e de mentira associadas tradicionalmente ao jogo do comediante a parte da inautenticidade. Mas ao mesmo tempo, ele torna mais leve essa parte de inautenticidade, livrando-a da pesada responsabilidade da escolha moral. $O$ homem ativo seria portanto aquele que afirma qualquer conduta com a qual ele possa desempenhar um papel. Por aí é que ele se situa além da moral.

“Tudo o que é imperativo e imoral se endereça à pluralidade das máscaras que nós carregamos em nós e que ordena que nós nos mostremos um e nos ocultemos de outro modo: portanto, que nós mudemos de aparência" (ibidem). O processo de "melhoramento", do "progresso moral": "recriar um novo homem", é indefinido mas ilusório, porque não se trata senão de uma mudança de aparência. Ora como Nietzsche sabe que não há outra coisa além das aparências, o homem mais afirmativo será aquele que recusará a fixação em um papel privilegiado (uma regra devida determinada), mas que desejará passar por uma série de estados e ideais, viver uma série de pessoas ou de personagens. - Ao vivê-las assim, sucessivamente, não seria porém exteriormente semelhante àquele que não vive senão alguns poucos papéis ou que os sofre passivamente? Ora esse que viveria não em série mas simultaneamente, numerosas personagens, freqüentemente contraditórias, não seria mais homem, mas o super-humano (sur-humain).

A afirmação da pluralidade dos papéis não é ela uma transição para o superhumano? Em todo caso, certos fragmentos nietzscheanos sublinham que a pesquisa ou a aceitação da pluralidade dos papéis deveria facilitar a afirmação do eterno retorno. “Nós não devemos (dürfer nicht) querer um estado único, mas nós somos forçados (müssen) a querer nos tornar seres periódi$\cos =$ semelhantes à existência (fragmento intitulado "A filosofia do retorno") (KGW VII 1, 1 [70]). A pluralidade dos papéis não seria senão aquela que possuímos como homens em estado de vigília, e nossos papéis de sonhador nos ensinariam sobre o caráter cíclico da existência. Por outro lado o francês "rôle", como no alemão "Rolle" (Nietzsche não o indica mas seria próprio da lógica nietzscheana tirar as conseqüências), deriva do latim "rótulus", de "rota", isto é, roda: "pequena roda".

Nietzsche pergunta se essa pequena roda ou enrolamento sobre si mesmo com o qual se carrega o texto do "papel" escrito em pergaminho, se cada anel desse enrolamento, não é como o cubo da grande roda do eterno retorno, que é o retorno de múltiplos papéis. Toda a existência é papel; quer dizer: a rotação incessante de papéis. Em um outro fragmento, que tem por título "O anel dos anéis", Nietzsche sugere, sem dizer expressamente, que afirmar a "pessoa" como ilusão, como potência metamórfica, ensina-nos a deixar de lado a identidade individual substancial e a afirmar o ciclo das identidades sempre provisórias, porque indefinidamente ou infinitamente sucessivas. Mas o ponto de vista da pluralidade interna não é apenas aquele de uma sucessão: trata-se daquele em que há uma coexistência "social" de pessoas. "O homem livre é ... uma sociedade de indivíduos" (VP I: 248). "O indivíduo é uma sociedade" (VP I: 268). Efetivamente nós entretemos com nós mesmos e em nós mesmos relações sociais tão complexas e numerosas o quanto são aquelas que nós entretemos 
com os que nos cercam. A representação da vida interior como um monólogo ou como um diálogo reflexivo, um simples desdobramento de si mesmo, parece ser uma redução intelectualista arbitrária desta vida social interior polimorfa que Nietzsche descreve:

"Nós jamais nos tratamos individualmente, mas de forma dupla, de forma plural; todas as inclinações sociais (amizade, vingança, inveja), nós a experimentamos devidamente em nós mesmos. Nosso egoísmo ingênuo e animal é gravemente alterado pela nossa prática social : nós não temos condições de sentir a unidade do eu, nós nos encontramos sempre entre uma multiplicidade de seres. Nós nos sentimos em numerosos seres e nós nos sentimos sempre novamente. Os instintos sociais (como inimizade, inveja, ódio) que supõem uma multiplicidade, nos têm transformado: nós temos transportado em nós a "sociedade", encolhida à nossa medida; retirar-se em si mesmo não é mais uma maneira de fugir da sociedade mas, freqüentemente, uma maneira de prolongar pelo devaneio e interpretar o que se passa em nós, segundo o esquema de nossas experiências anteriores..." (VP I: 255).

Esta "prática social" intra-individual não está mais ligada a uma vida social exterior, da qual ela seria, por exemplo, a antecipação ou a lembrança, como se esses papéis fossem a repetição de discursos que nós possuiríamos ou que nós houvéssemos dirigido aos outros. Trata-se, ao contrário, da interpretação conforme ao esquema da socialidade de nossa experiência "solitária". Que "nós" dirijamos a nós mesmos o amor, o ódio, a recompensa ou a culpa: eis um dado de fato, observável por todos, válido para todos e que, no entanto, apenas alguns reconhecem. O "nós" da descrição é aqui ambíguo. Todo o indivíduo é uma so- ciedade, mas apenas "o homem livre" é capaz de perceber essa pluralidade de maneira positiva, como algo digno de ser reivindicada e de ser convertida de fato em ideal.

Desse modo, portanto, a origem dessa permanênecia do esquema da socialidade parece se situar na submissão imemorial do indivíduo ao rebanho. Se o indivíduo carrega em si os papéis sociais, é como um traço, uma marca profunda de sua dependência arcaica e total com relação à sociedade. "Antigamente o eu se escondia no rebanho, hoje o rebanho se oculta no fundo do eu" (VP I: 256). Nietzsche levanta a hipótese segundo a qual nas épocas primitivas o indivíduo inicialmente vivia inteiramente fundido na coletividade, como se fosse a parte de um organismo. A coletividade se serve durante longos períodos do indivíduo como se serve de um órgão. Nesse estágio, onde não havia indivíduos independentes, os únicos instintos, sentimentos, condutas eram aqueles que concerniam ao homem enquanto membro da sociedade. É por isso que, ainda hoje, o ódio ou o desgosto de o que prejudica a sociedade é, em nós, mais "primitivo", mais imediatamente "nosso" que todos os sentimentos egoístas. Mais tarde, quando a sociedade perde sua potência total sobre os indivíduos, os instintos originariamente coletivos entram em conflito com as finalidades individualistas que lhes são atribuídas. No entanto, não é sobre a base de uma livre invenção de si, mas a partir de uma modificação dos instintos coletivos que o indivíduo emancipado frente ao organismo social encontrará sua identidade própria: ele virá "a criar sua possibilidade de existência individual graças a uma reorganização, uma assimilação, uma eliminação dos instintos dentro dele" (VP I: 249). Para Nietzsche, o "individual" não tem conteúdo senão derivado: ele é uma transformação, uma remodelagem, uma nova interpretação dos instintos sociais; quer dizer: de práticas sociais determinadas e, enfim, de julgamentos que pertencem originariamente a um quadro 
social necessariamente revolucionado do ponto de vista histórico. De fato, é preciso que muito tempo tenha passado para que as práticas sociais tenham podido se fixar sobre a forma de "instintos". Portanto, é sempre contra uma outra sociedade que não a sociedade atual que o indivíduo se revolta.

Notemos de passagem que a concepção heideggeriana do Dasein "autêntico" constitui uma variante desse tema nietzscheano: o Dasein, para conquistar seu ser próprio, deve afirmar como suas as possibilidades que ele teria colocadas no "se". Da mesma forma que o eu se encontra inicialmente fundido no rebanho, a primeira e mais fundamental identidade do Dasein é o "se" em si sesmo (Man-selbst). O que separa radicalmente Heidegger de Nietzsche é o fato de que para o primeiro as possibilidades são "existenciais", visadas transcendentais e não possibilidades instintivas, isto é: corporais. A margem de liberdade, de livre invenção de si, é muito mais fraca em Nietzsche, na medida em que a dificuldade de reinterpretar os instintos sociais sempre mais imperiosos e rígidos (o patriota ou o homem de partido são capazes de muito maior paixão ou de maior ódio "inocente", diz Nietzsche, do que a maior parte dos indivíduos que perseguem fins individuais) - é muito maior que a dificuldade de passar do se à própria ipseidade (por exemplo do "morreu-se" ao "eu me relaciono com a minha morte").

Exatamente essa dificuldade a qual se furta a posição do ego individual é a que conduz Nietzsche a uma crítica paradoxal do egoísmo. Como se pode falar do egoísmo, criticar o egoísmo, pois que não há verdadeiro ego? O egoísmo também é algo inexistente ou tão fraco quanto o próprio ego. "O egoísmo ainda é de uma fraqueza infinita" (VP I: 256). "O egoísmo é uma coisa de algum modo tardio e ainda muito rara..." (UW II: 171). Antes de qualificar uma ação como egoísta, é preciso se perguntar se um ego, e qual tipo de ego, se encontra no seu ponto de partida. Porque o ego é mais geralmente muito pouco emancipado em relação à coletividade e porque ele é de toda maneira um anel - consciente ou não - da cadeia dos seres vivos, um produto - consciente ou não - do passado histórico, a maior parte das ações que nós chamamos egoístas é efeito quer das "paixões gregárias", quer das necessidades ou das tendências que pertencem à espécie ou à linha, e não ao indivíduo! $\mathrm{O}$ cuidado ao se vestir, o desejo de fazer fortuna ou a ambição política não são nem mais nem menos egoístas que o instinto de conservação ou o desejo sexual. Aí falta o verdadeiro egoísmo. O ego individual desaparece quando o indivíduo satisfaz totalmente uma função, quer ela seja simplesmente biológica (o prazer de se alimentar, o prazer sexual ), ou social e diversificada: os grandes "papéis", como são o de príncipe, de profeta, de poeta, implicam com apagamento, uma verdadeira supressão do indivíduo (KGW V 2, 12[93]).

Nietzsche mostra que o imperativo que comanda aí, sobretudo quando ele é de ordem fisiológica, é praticamente impessoal, ainda que de modo paradoxal o imperativo moral que exige que não se satisfaça ou se restrinja os desejos seja incontestavelmente inspirado pela pesquisa de uma certa imagem de si mesmo. “No egoísmo comum, é justamente o não-ego, o profundo ser banal, que domina" (KGW VVV 2, 26 [262]). Ainda que a sensualidade seja muito banal para definir um verdadeiro egoísmo, a moral tem o eu em estima muito mais alta do que o exige um egoísmo extraordinário.

\section{Desenvolver a dimensão cósmica do eu}

Não basta constatar que o eu não existe separadamente do mundo. É preciso concluir que o eu é seu mundo e, pouco a pouco, o mundo ou os mundos físicos, biológico e natural, histórico e social, intelectual ou espiritual inteiramente. "Absorvemos em nós 
mesmos não apenas Deus, mas todos os seres cuja existência nós reconhecemos, mesmo que sem os nomear; nós somos o cosmos, na medida onde nós o compreendemos ou sonhamos. As oliveiras e as tempestades se tornam parte de nós mesmos; da mesma forma que a bolsa de valores e o jornal" (VP I: 255). Como mais tarde em Heidegger, não há sujeito diante do mundo, mas um ser no mundo. O homem não desenvolve possibilidades próprias senão na medida em que elas the são oferecidas por seu mundo. Não há mundo puramente "exterior", o que não significa ausência de interiorização, ausência de uma esfera privada. Nietzsche zomba da ridícula superestimação do homem em relação ao mundo e da falsa simetria que reside na atual fórmula "o homem e o mundo" e que age como se houvesse a menor igualdade entre os dois termos. O perigo que ameaça a individualidade nietzscheana não é como, em Heidegger, a da "queda" (o Verfallen); isto é: a terrivelmente grande identificação com o mundo circundante, mas, ao contrário, a percepção muito fraca dos múltiplos laços de imbricamento do homem com este mundo. O ser afirmativo, nobre, aceita e reivindica o maior fundamento cósmico possível.

$\mathrm{O}$ eu se engrandece primeiramente se ligando a toda a linha da evolução, se integrando à arvore da vida, a partir de suas formas mais elementares. Deve necessariamente existir uma continuidade absoluta, com transições ininterruptas, desde a primeira fórmula viva até o "eu". Isso deve bastar para reduzir as absurdas pretensões do indivíduo: este não é um fruto destacado, mas o resumo, a repetição de toda a ascendência não apenas da espécie mas do ser vivo em geral. Cada uma de nossas ações é como uma retomada abreviada de toda a história da vida. Todo ato é uma repetição, não de um "eu", mas do conjunto da vida. Em numerosos fragmentos, $\mathrm{Ni}$ etzsche não deixa de sublinhar que "o homem não é apenas um indivíduo, mas a totalidade do orgânico que continua a viver nele" (WM § 676). "O indivíduo é a vida em sua totalidade, tal qual se desenvolveu até então, e não o resultado disso tudo" (ibidem). "Cada ser singular é precisamente o processo inteiro em linha reta ( não apenas 'hereditário' mas ele mesmo...)..." (KGW VIII 2, 9[30]). "O ego vale cem vezes mais que uma unidade na cadeia dos membros; ele é a própria cadeia em sentido absoluto" (ibidem 199, 10[136]; nós sublinhamos). Em toda operação do inconsciente ou mesmo em toda percepção, o passado orgânico se reativa e se prolonga em sua totalidade, muito mais do que em cada ato consciente refletido: "Em todo o julgamento dos sentidos, toda a pré-história orgânica entre em jogo..." (VP I: 228). Como "resumo" de todo passado da linha biológica, o indivíduo é da mesma forma portador de todo o futuro desta linha. O indivíduo joga e arrisca mais que seu próprio futuro egoísta, mesmo quando ele crê que age por sua única conta. "Nós somos mais que indivíduos: nós somos também toda a cadeia, com todas as tarefas de todos os futuros desta cadeia" (WM § 687).

“O homem, até o presente, foi o embrião do homem do futuro. Todas as forças plásticas que tendem na direção deste futuro estão nele mesmo; e como elas são prodigiosas, resulta daí um sofrimento para o indivíduo existente, na medida em que ele contribui a determinar o futuro. Eis a concepção mais profunda do sofrimento: são as forças plásticas em conflito. Não é preciso que o isolamento do indivíduo nos iluda: na realidade, há uma corrente comum que atravesse todos os indivíduos." (VP I: 390; nós sublinhamos - $\mathrm{MH}$ )

Uma das causas mais profundas de sofrimento para o indivíduo seria, portanto, a desproporção entre sua realidade presente e as forças (que dentro dele mesmo lhe são maiores) que trabalham para preparar o nascimento da humanidade futura. Nietzsche, ao designar essas forças como 
uma "corrente comum" lançada em direção ao futuro, fornece aqui uma versão aparentemente substancialista e evolucionista da vontade de potência [volonté de puissance] enquanto conjunto das forças que, de um lado, forma o substrato biológico comum a todos os indivíduos e, de outro, se conjugam em uma nuvem universal e progressiva em direção a um tipo superior ao do homem atual. Uma tal definição "realista" da vontade de potência não a distinguiria de um vitalismo do tipo do querer viver schopenhaueriano ou do impulso vital bergsoniano. Ora essa definição se encontra de fato constantemente redobrada, compensada, corrigida por uma versão não realista, "perspectivista" da vontade de potência como interpretação dos fenômenos a partir do ponto de vista de tal ou qual força ou, melhor dizendo, de tal ou qual relação de forças. Do ponto de vista de um indivíduo que escolhe seus valores, quer dizer sua maneira de concretizar o imperativo de "ser mais", próprio a toda vida, há uma ruptura, um desvio frente à "corrente comum": o índice máximo desta ruptura - colocada numa linha que se dirige ao futuro é o super-homem [Sur-homme]. Mas não é contraditório apresentar a vontade de potência, por sua vez, como a unidade do meio vivo e como o jogo das forças, dispersas em múltiplas perspectivas, isto é: ao mesmo tempo como identidade infinita e como diferença infinita? Não há "contradição" senão para uma lógica que deseja evitar a contaminação do um pelo múltiplo, que deseja que de alguma forma subsista uma identidade pura. A vontade de potência é ao mesmo tempo una e múltipla, nela mesma e em cada uma das individualidades nas quais ela se divide originalmente. Quando Nietzsche enuncia "a hipótese" segundo a qual se poderia "chamar toda energia em ação de vontade de potência" (ABM § 36), ele toma o cuidado de precisar que essa definição empresta ao mundo um "caráter inteligível", quer dizer, em termos kantianos, ele se pronuncia sobre o "em si" da realidade. Não se deveria fazer da von- tade de potência uma unidade substancial subjacente.

Mas então por que falar de "corrente comum"? Nietzsche se deixa entreter pela metáfora da "corrente" quando ele afirma uma coisa totalmente distinta da que diriam um Schopenhauer ou um Bergson. O que afirma ele? Não que uma energia originalmente única se divide em múltiplos indivíduos, quando ela se faz "mundo", como diria um, ou quando ela "cria", como diria o outro; mas, bem ao contrário, que toda formação individualizada participa de uma estrutura única que se move a partir de uma única fonte pelo fato de que ela obedece por toda parte a uma mesma lei. Quando Nietzsche escreve: "É a mesma força que se gasta na criação artística e no ato sexual", ele acrescenta também: "Não é apenas um tipo de força" (es gibt nur Einer Art Kraft) (VP I: 334). A força é do mesmo gênero (Art) por toda parte: ela é o que aparece.

Também se deve lembrar que essa afirmação de uma unidade não substancial, mas estrutural e unificadora, típica, relativiza a procura da multiplicidade, notadamente a intra-individual. Esta busca não repousa sobre uma quietude e uma segurança profundas? Na medida em que se foi tão longe do lado da divisão do eu, o perigo da dispersão irrecuperável, o caos infecundo, não é conjurado pela existência mesma desta estrutura unificadora? Nietzsche não pode se jogar tão alegremente na direção do múltiplo senão porque ele não duvida que um unificador constitui de uma certa maneira o "fundo das coisas"? A pesquisa incansável da pluralidade e a visão do carácter proteiforme do ego e do mundo seriam, então, como a contrapartida da vida mesma do um, a respiração, a pulsação (o fluxo e o refluxo) de uma identidade que se furta sem parar e que se reencontra ela mesma sem parar. E quando Nietzsche descreve que "o mundo" como "um mar de forças envolvido em tempestade e em fluxo perpétuo, eternamente em vias de mudança, eternamente em movimento de refluxo, 
como grandes anos de retorno regular, um fluxo e um refluxo de suas formas, indo das mais simples às mais complexas, das mais calmas, das mais fixas, das mais frias às mais ardentes, às mais violentas, às mais contraditórias, para voltar em seguida da multiplicidade à simplicidade, do jogo de contrastes à necessidade de harmonia, afirmando ainda seu ser nessa regularidade de ciclos e de anos..." (VP I : 216; nós sublinhamos), é preciso confessar que a relação estabelecida neste texto entre o múltiplo e o um funciona segundo uma estrutura platônica: o ser (o um e o idêntico) se encontra afirmado através do devir (o múltiplo e o diferenciável) como o que lhe confere a perfeição, isto é: a "santidade" (ele mesmo o diz um pouco mais adiante nessa mesma passagem). Não há platonismo no sentido em que haveria uma transcendência do um, mas no sentido de uma participação - aqui imanente - da pluralidade à unidade. No entanto é preciso evitar tirar dessas formulações conclusões gerais e definitivas sobre o caráter tradicionalmente metafísico da vontade de potência e do eterno retorno, porque outras fórmulas, como veremos um pouco mais abaixo, acabam corrigindo e inflexionando aquelas que acabamos de citar.

Passando a tratar agora não mais da evolução da vida mas da história humana, parece difícil que o indivíduo possa aí se dissolver, possa aí se integrar de maneira orgânica. Como o homem individual poderia recapitular espontaneamente a totalidade ou mesmo uma parte do passado humano? Uma herança histórica não se recebe de maneira "automática", como um capital genético: é preciso que o passado coletivo penetre na consciência, seja avaliado, seja conhecido. "Nós temos a consciência de que a história tem ela mesma um sentido absoluto" (Nachlass, 1887-1888, 11[374]). Por "nós", Nietzsche entende todo indivíduo. "Todo homem é uma causa criadora de história" (KGW VII 1, 4[138]). Mas de qual maneira? Não se trataria de um hegelianismo invertido, quer dizer: de uma recuperação da totalidade do passado, não no contexto de um espí- rito absoluto, mas na subjetividade individual elevada ao absoluto? Em primeiro lugar considere-se que o termo "absoluto" que qualificaria a relação do indivíduo com a história não designa Nietzsche uma totalidade, mas uma soberania, no sentido em que o indivíduo tem de decidir soberanamente, quer dizer de modo solitário (absoluto) em uma relação íntima e particular, relativamente à significação do passado histórico, jamais objetivamente estabelecida de uma vez por todas, mas sempre capaz de se reafirmar, se transformar ou de ser negado mas - em todo caso - a ser prolongado. Isso quer dizer, em segundo lugar, que não há lugar nem no indivíduo, nem fora dele, onde a história possa se tornar universal, quer dizer venha a alcançar uma síntese conceitual ou retrospectiva. $\mathrm{O}$ indivíduo não pode se relacionar (fora da ficção da objetividade historicizante) "absolutamente" em relação à história senão pela identificação ou pela assimilação afetiva e prospectiva.

A ausência de totalização, o ponto de vista experimental e antecipador faz com que a noção nietzscheana fundamental de "sentido histórico" escape a qualquer tipo de hegelianismo. Nietzsche opõe constantemente, desde a segunda consideração intempestiva até a Gaia Ciência e além, a significação hegeliana do sentido histórico a sua própria, descrevendo esse "sentido" ao mesmo tempo como a melhor e a pior das faculdades ou disposições do espírito. Será pior se ele for concebido, à maneira hegeliana, como o sentido do determinismo, do peso do passado, do movimento irresistível e inevitável dos acontecimentos, que nos faz curvar a cabeça e leva a adorar os "fatos" e "a ordem estabelecida". Ele é igualmente perigoso na medida em que a hipertrofia de um saber que não tem outra finalidade senão a de alcançar o saber e que por uma acumulação indigesta de conhecimento sobre as épocas as mais diversas termina por introduzir o relativismo e o distanciamento, além de levar à paralisia de toda a ação. O perigo é, enfim, o de que 
o "sentido histórico" leve ao jogo frívolo com os ouropéis e os despoje do passado do qual o homem moderno se reveste com uma compulsividade desesperada.

O século XIX constitui "a primeira época erudita em matéria de costumes morais, artigos de fé, gostos estéticos, religiões..." (ABM § 223). O "sentido histórico" que permite situar todos os sentidos morais, intelectuais, artísticos, religiosos, de conhecer todas as maneiras, de compreender todos os julgamentos de valor passados, torna incapaz de aderir a algum momento ou figura da tradição, não mais do que em relação ao presente. O homem moderno faz um uso niilista da história: não crendo em nada, ele se serve dela como de uma revista de roupas e de acessórios. Ele se mascara de clássico, romântico, cristão ... flutua, erra através de todas as máscaras possíveis, que assediam os bastidores da história universal, esse grande teatro, cuja cena é mantida ocupada por um desfile multicolorido de carnaval. A única saída para o desespero que oculta essa frivolidade é no sentido de empurrar o jogo até a sátira, até a paródia: em lugar de sermos comediantes por desespero, trata-se de sermos atores deliberados, "parodistas da história universal" (ibidem).

Se o projeto de uma paródia da história universal ainda pode ser interpretado como uma reação anti-hegeliana, há toda uma outra significação do "sentido histórico" que nada tem de hegeliano e que consiste, para um indivíduo, em ter a força necessária para considerar todas as experiências humanas como suas próprias experiências. Tal disposição de espírito nada tem a ver com o humanismo intelectualista e universalista, para o qual "nada do que é humano me é estranho". Não se trataria de um conhecimento abstrato do homem em geral, mas da participação afetiva e individual na história como participação em um conjunto de experiências aproximativas ("a história é o grande laboratório de ensaios" [UW I: 244]). Tratar-se-ia de perceber a história do ponto de vista não dos seus resul- tados adquiridos, mas das possibilidades futuras que nela se descobrem. A Gaia Ciência (§ 337) descreve o que poderia ser um futuro e um ainda inexistente "sentido histórico", um sentimento da história que não seria mais dominado pela melancolia do olhar sentimental e retrospectivo, mas pela alegria ligada à descoberta de nossas novas possibilidades criadoras. O homem que fosse "capaz de experimentar a história dos homens em seu conjunto como sua própria história", que pudesse "condensar em um único sentimento" as derrotas e as vitórias de toda a humanidade, passaria antes de tudo pela fase - que nós podemos chamar hegeliana - de abatimento, de azedume, de cansaço infinito relativamente ao conjunto do passado. Mas se esses heróis do fim de tarde tivessem a força para afirmar que esse passado não existe senão em vista de um devir, que esse passado não era senão uma primeira tentativa, um primeiro ensaio, se pudesse acontecer desses heróis que, "ao se erguer o segundo dia de batalha, saúdam a aurora e sua oportunidade", ele seria preenchido por um sentimento de felicidade transbordante e quase divino. Esse homem incorporaria toda a história passada como um único dia, apenas por acreditar em um "segundo dia". Longe de ser passivamente absorvido pela história, ele a absorveria, ele a colocaria para trás de si, se apoiando nela pela simples afirmação da oportunidade que representaria um amanhã.

Não está em questão aqui pesquisar o que a segunda intempestiva chamava de história monumental, os exemplos de grandes homens ou de grandes ações a imitar. Assimilar-se à história como sua "própria história" é poder dizer da história e de si mesmo ao mesmo tempo: não somente eu fui, eu sou isso, mas isso "morreu" e continua através de "mim". A fórmula aparentemente insensata que citamos freqüentemente: "No fundo, todos os nomes da história sou eu" (Carta a Burkhardt, 6/01/1889) (fórmula que pertence efetivamente aos raros escritos da fase de "loucura" de Nietzsche) pos- 
sui equivalentes "racionais": "Quando eu falo de Platão, de Pascal, de Espinosa e de Goethe, eu sei que seu sangue corre em minhas veias..." (VP I: 386). "Em tudo o que comoveu Zoroastro, Moisés, Maomé, Jesus, Platão, Brutus, Espinoza, Mirabeau, eu já estava presente e ainda que sob diversas relações é em mim apenas que morre e nasce o embrião que teve a necessidade de que isso tudo tivesse ocorrido alguns séculos atrás... - o sentido histórico ainda está por nascer" (ibidem).

A idéia de que a relação com o passado, a continuidade histórica, ao menos sob o plano da história do pensamento, constitui um laço orgânico comparável aos "laços de sangue", a transmissão de características hereditárias ("seu sangue".... "o embrião que tem a necessidade de alguns séculos") - essa idéia implica uma assimilação metafórica entre a formação de um eu que pensa particular, através das diversas figuras históricas, e a formação de um único organismo, através de diferentes fases. Um laço mais obscuro, mas mais estreito - um laço "corporal" de parentesco, de ascendência, se encontra substituído por Nietzsche às relações intelectuais habitualmente estabelecidas de precursor, de modelo ou de rival. Essa noção de parentesco não significa que o eu atual do filósofo dela seja o resultado, o produto racional do desenvolvimento lógico desses pensadores anteriores. De fato é apenas "sob algumas relações", e não totalmente, em si e para si, que esse eu atual se revela como produto de o que se estabeleceu incubadamente entre os seus predecessores ilustres.

Mas de qual "eu" se trata aqui? O que significa "eu já estou presente"? É certo que se trata de um eu filosofante, de uma variedade do ego cartesiano? Notaremos que Nietzsche não diz: eu estou presente em tudo o que pensou Zoroastro, Moisés etc. ... mas sim que esteve presente em tudo o que foi "emitido": isto é: em tudo que pertence ao corpo de Zoroastro, de Moisés, etc.: à vontade de potência que se manifesta neles. De outro lado, apenas a primeira enumeração: Platão, Pascal... exemplifica uma série de pensadores. $\mathrm{Na}$ segunda lista, onde dominam os fundadores de religiões e onde figuram duas personagens históricas ligadas a acontecimentos violentos (o assassinato de Cesar, a Revolução Francesa), não há senão dois filósofos. Não se trata, portanto, de uma ascendência puramente filosófica, mas de algum ponto de semelhança maior, que talvez diga respeito ao conjunto do horizonte histórico. Não há com efeito nada em comum com essas personagens senão que elas têm, como se disse, "a marca da história".

Nietzsche considera sua revelação do niilismo e do eterno retorno como um acontecimento que, "de maneira verossímil, quebrará a história em dois pedaços" (O Caso Wagner): "Um dia meu nome será associado à lembrança de alguma coisa prodigiosa, a uma crise como jamais houve na Terra..." (Ecce Homo, 1). A relação que seria então transistórica seria a relação com o que na história representa o destino. "Eu sou um destino" (ibidem). Como os nomes da lista, o nome de "Nietzsche" é e será sempre associado a uma crise ou a uma virada da história ou do destino; a uma ruptura e a um novo começo, o que supõe por sua vez uma continuidade. Em qual medida e como essa continuidade não somente entre os nomes dessa lista, mas também entre "todos os nomes da história", quer dizer entre todas as figuras que fizeram época e que são "nomes", é determinada pelo eu de Nietzsche?

Revertendo o hábito do pensamento que consiste em identificar a sucessão cronológica com a causalidade e que consiste em considerar que o "eu" presente não pode ser senão o resultado do desenvolvimento anterior, Nietzsche não formula um paradoxo, nem uma idéia delirante de toda a potência divina: sua posição se apóia sobre uma dupla consideração relativamente ao tempo. De um lado, o passado sobrevive no presente (o presente começou muito antes de surgir com o presente); de outro lado, o futuro condiciona certamente o pre- 
sente, mas também até o passado mais recuado (o que acaba modificando o sentido do que foi e de o que é). De um lado, de fato, é preciso transpor ao plano dos indivíduos históricos o que vale para o indivíduo biológico: não é somente ele mesmo seu sentido estreito de atualidade, ele é "toda a cadeia" - até chegar até ele - dos momentos da história. Os pensadores com os quais Nietzsche se liga ou contra os quais ele se bate não apenas estão presentes nele; por sua vez ele está presente neles como um desenvolvimento embrionário. Isso vale para toda relação histórica fundamental. Napoleão teria podido dizer: na Revolução Francesa: eu já estou presente. De um outro lado, essa presença antecipada significa: o pensamento que Nietzsche torna manifesto - em particular o lirismo, a negação dos valores mais altos - já deve estar presente, de modo latente, involuído, mas claro, na posição platônica, cristã, racionalista, dos valores mais altos. As revelações do futuro rondam, trabalham o "passado". Todo pensador estende sua influência não apenas sobre a posteridade, mas para muito longe antes de si mesmo: Nietzsche já rondava Platão, definido-o intimamente.

Mas como pôr de acordo essa visão de uma história tecida por linhagens e ascendências secretas, de uma história desligada da cronologia mais estreita, e no entanto fundada sobre a idéia de um crescimento espiritual que progride através de múltiplos indivíduos, com a afirmação cardeal da filosofia nietzscheana, aquela do eterno retorno do mesmo? O retorno do idêntico não exclui toda gênese e todo desenvolvimento? Não é preciso crer ou na história ou no eterno retorno? Em realidade, não existe dilema ou contradição entre a historicidade e o eterno retorno, senão concebendo o eterno retorno como um fato, como um modo efetivo de existência da totalidade do existente. Ora o eterno retorno não é uma dimensão cósmica factual, nem "em si mesmo", nem como uma lei objetiva universal da natureza (ainda que Nietzs- che, embora não para fundar seu pensamento, tenha formulado hipóteses nesse sentido, sobretudo para procurar confirmação nas ciências físicas de seus pensamentos "abissal"). Afinal de contas, o eterno retorno reenvia a uma experiência - singular - de um indivíduo na história, ou a uma experiência feita por um indivíduo em um momento particular relativamente a sua história e a história em geral. Essa experiência na qual "tudo retorna, retornou, retornará" - a experiência da eternidade - é intra-histórica, mas aquele que afirma sua validade absoluta escapa à história entendida como desenvolvimento objetivo, homogêneo e universal.

Nietzsche situa o anúncio do eterno retorno no "centro" da "história mundial". Ele freqüentemente também o chama de "a virada" da história. "No momento no qual este pensamento se faz presente tudo toma uma outra cor e se trata de uma outra história que começa" (VP II: 28, sublinhado por MH). A doutrina do eterno retorno deve modificar antes de mais nada a compreensão da história e, paulatinamente, o próprio estilo de seu transcurso: "A história do futuro de mais a mais, é esse pensamento que importará..." (VP I: 287). Nietzsche profetiza uma lenta impregnação da humanidade por este pensamento: essa doutrina levará, diz ele, "milhares de anos" para se impor a "toda a humanidade futura" (ibidem). Ela joga, portanto, um papel intra-histórico. Mas ela não é menos supra ou extra-histórica, sobretudo porque ela é supra ou extratemporal ( o instante onde se revela o retorno contrai o futuro no passado, projeta o passado em um futuro ilimitado); em seguida porque ela depende de uma adesão tão estreita e tão íntima do indivíduo a seu fatum (como a qualquer fatum) que ela não pode se manifestar sobre a cena da história. A consciência histórica não pode senão rejeitar a idéia de afirmação de um "eu estou no mundo de uma vez por todas", porque ela não vê aí senão a resignação, o fatalismo da fraqueza, a renúncia a todo o progresso. Enfim, a idéia de uma harmonia ou, 
ao contrário, de uma fusão, secreta e sem falta, entre o eu e o mundo (o que se exprime pela fórmula ego factum) lhe parece sinônimo de estatismo e escapa por princípio à dialética histórica, fundada sobre a oposição do eu e do mundo e em sua transformação recíproca.

Mas essa fusão sempre singular não é anunciada senão como uma possibilidade (se tu crês profundamente que tudo volta, o que disso resultará para ti e para o mundo?), e não como uma modalidade objetiva de existência das coisas. Parece difícil de seguir aqui a leitura heideggeriana, que interpreta o eterno retorno como provindo da categoria metafísica da existência e em relação à qual a vontade de potência seria a essência. "O modo segundo o qual o existente em sua totalidade - no qual a essentia é a vontade de potência - o modo sobre o qual o existente em sua totalidade existe, sua existentia, é o eterno retorno do mesmo". ${ }^{6}$ Para conceder essa função ao eterno retorno, Heidegger se baseia principalmente sobre o fato de que ele a relaciona com a totalidade do existente. Ora assim fazendo, ele passa silenciosamente não apenas sobre as numerosas reservas que Nietzsche associa a sua formulação de um conceito de totalidade (em particular a idéia de que a totalidade do círculo do retorno não deveria ser quebrável, lacunar, imperfeita: isto é, não deveria ser um círculo vicioso), mas a impossibilidade de conferir a essa totalidade o caráter de objetividade tanto quanto o de subjetividade. $\mathrm{O}$ eterno retorno não pode ser convertido em lei universal e objetiva da natureza, pois depende de uma afirmação singular; mas também não se deveria dizer que "tudo volta" é apenas subjetivo, porque isso seria colocar-se no ponto de vista totalmente fictício de uma objetividade em si, situada fora de toda perspectiva.

Para o indivíduo que afirma o retorno, a extrema subjetividade se reencontra com a extrema objetividade. Mas esse grau de afirmação é tão elevado que para ele ainda não existe uma humanidade que dela seja capaz (o homem é um ser niilista que prefere crer em sua desaparição para sempre, ao invés de seu retorno). O indivíduo que afirmaria o retorno seria o superhomem [Sur-homme]. Por isso é preciso manter o caráter condicional, hipotético, de um tal grau de afirmação. Para fazer do eterno retorno uma proposição metafísica clássica, Heidegger deve desviar-se da forma do condicional e dizer "o eterno retorno do mesmo enuncia como é a totalidade do existente..." (ibidem, p. 32). Ora, o eterno retorno enuncia como seria a totalidade para aquele que a afirmasse sem restrições, sem a menor reserva a respeito de um da capo eterno. Se Nietzsche pode distinguir entre aqueles que não acreditarão em suas palavras e que, portanto, não terão consciência senão de uma existência fugidia e aqueles que, nele crendo, terão sua vida marcada pelo sinal da eternidade, é bem porque o eterno retorno não constitui, como crê Heidegger, o modo de existência da totalidade do existente; é porque, rigorosamente, o eterno retorno escapa à metafísica, porque nenhuma metafísica se funda sobre uma proposição hipotética, mas, ao contrário, procura sempre o incondicionado, o anhypothèton. Qualquer metafísica é um discurso sobre a phusis, uma física, um realismo. $\mathrm{O}$ pensamento do retorno como pensamento de uma experiência possível do mundo é irreal e irrealista.

$\mathrm{O}$ eterno retorno contém em si mesmo, por isso, uma crítica implícita da tendência realista, dirigindo-se no sentido de uma ampliação da subjetividade individual pelo lado de seu enraizamento em um mundo orgânico e histórico. Desenvolver a “dimensão cósmica do eu" representa uma reconquista da densidade carnal, da terra, dos laços que fazem com que o sujeito jamais seja insulado. Nesse sentido, a fórmula [acima] não deve ser renegada. Mas essa conquista continua sendo desprezível em comparação com a verdadeira transmutação da subjetividade que consistiria na supressão da velha oposição entre o ego e o mundo. Falar de uma "dimensão cósmica do eu" é sempre e ainda tomar o eu como 
base e como ponto de partida. Nas fórmulas: ego fatum, amor fati, quem é o sujeito? Não é também o fatum? Porque o amor no amor fati não é, como pensa Heidegger, o supremo esforço da vontade para querer um "objeto mais alto", a totalidade do existente em seu incessante retorno [Nietzsche I 365]: esse "desejo do destino" não tem apenas o sentido do genitivo "objetivo", mas também o do genitivo "subjetivo", na medida em que é essa totalidade ela mesma, o "fatum", que assume esse desejo ou essa vontade. E se existe um querer, trata-se de um querer receber, um querer aderir, que não deveria ser objetivante. A vontade e o sujeito não são eles metamorfoseados, "neutralizados", na medida em que eles são queridos pelo fatum? A afirmação sem reserva do fatum significa que o fatum se afirma através do "eu". Essa reversão transfigura a vontade (Heidegger interpreta o "amor fati" como uma "vontade transfigurante de pertencer ao destino" mas não é ela, ao contrário, uma vontade transfigurada por seu pertencimento ao destino?) suprimindo o primado da subjetividade.

Mas o que é o fatum? Ele não é apenas o encadeamento objetivo, colocado fora do eu, de todos os eventos do mundo suscetíveis de me conceber e capaz de serem concebidos como inevitáveis e determinados por princípio. Fatum, de fari - dizer - é "o dito" que não provem de mim, a palavra entendida - de onde ela viria? De um Deus, de um demônio (GC § 341), de uma potência sobre-humana - que me sussurra na orelha a assustadora e exultante revelação: "Tu és isso, tu o fostes e tu o serás" e, ademais, "tudo retorna, retornou e retornará". Na fórmula ego fatum, é impossível separar o que pertence ao ego como sujeito do que pertence ao fatum, que não é um objeto, mas algo que de alguma forma é mais sujeito do que o sujeito. Aqui o ego não se coloca ele mesmo de maneira totalmente segura e transparente, como na metafísica tradicional da subjetividade: ele provém de uma palavra, do dizer-se fatum, e não é compreensível sem a totalidade do fatum que o compreende se compreendendo nele mesmo.

Diante das riquezas das análises críticas e das tentativas feitas por Nietzsche para responder à questão da subjetividade, não podemos, no término deste percurso, aceitar a idéia heideggeriana, segundo a qual a filosofia nietzscheana perpetua pura e simplesmente o modelo clássico da metafísica do sujeito nos tempos modernos e que ele leva essa última a seu "acabamento". Certamente Heidegger tem razão ao mostrar que a essência da subjetividade não reside no primado conferido ao eu, mas sobretudo na posição de um sub-jectum (Nietzsche II 238), isto é: de um substrato subjacente que joga o papel de fundamento último e absoluto. Para ele, Nietzsche teria conferido à vontade de potência enquanto corpo essa função de subjacência fundadora e incondicional. Porém, essa interpretação é redutora em diversos pontos. De início ela negligencia o fato de que a vontade de potência não se encontra jamais identificada a uma substância e, sobretudo, não constitui uma base sobre a qual se desenvolvem os fenômenos, pois é tão-somente a sua estrutura interpretativa. ${ }^{7}$ De outra parte essa leitura não leva em conta a colocação em questão radical através da qual Nietzsche questiona a oposição sujeito e objeto. A metafísica tradicional do sujeito implica a noção de uma representação objetiva ou objetivante. Ora o próprio Heidegger reconhece que o "estado estético", tal qual é descrito por Nietzsche e que, como tal, manifestaria "a expressão mais transparente da vontade de potência ", escapa à dualidade sujeito-objeto. "A beleza não é exatamente o objeto dado de uma representação pura ... O estado estético não é nem alguma coisa de subjetivo, nem alguma coisa de objetivo" (Nietzsche I 116). Da mesma forma que a beleza, o fatum, qualquer que seja o sentido que lhe atribuamos, não é objetivo, nem subjetivo. Pelo menos, é preciso confessar que a noção de representação de um objeto sobre a cena da subjetividade se encontra fortemente abalada. Finalmente, a 
interpretação heideggeriana desconhece o fato de que o ego fatum não seria senão uma expressão hipotética do eterno retorno, uma supressão possível das antinomias entre o eu e o não-eu, a liberdade e a necessidade, a atividade e a passividade que leva à ruína do sub-jectum. Pode-se concluir que o sujeito soçobra em um abismo, na vertigem do eterno retorno ou na loucura, mas que em nenhum caso o sujeito metafísico subsiste imutável como o fundamento venerável e inquebrantável.

Restaria elucidar as razões que fizeram Heidegger explorar uma construção tão pouco defensável. Sua própria aspiração a encontrar uma identidade "autêntica" para o Dasein, uma totalidade definida e uma finitude acabada, sua desconfiança em relação à dissipação do sujeito na multiplicidade (das ocupações, por exemplo) seguramente não são estranhas à matéria, mas é preciso deixar essa interrogação para mais tarde.

Pode-se dizer que Nietzsche mudou a essência da subjetividade? O "eu plural", o "eu cósmico" não são senão ensaios para contornar o fato massivo do ego e, no entanto, contra uma longa tradição (à qual o primeiro Heidegger em parte também pertence), que identifica o indivíduo com o fechamento sobre a intimidade consciente, contra a procura quase sagrada do próprio, da esfera privada, Nietzsche esboça a possibilidade, talvez mais oriental que ocidental, de um indivíduo aberto, ou em todo o caso cujos limites não sejam definidos nem pela consciência de si, nem pelo autoposicionamento, nem pela segurança de uma identidade indivisível. Retornando a Heráclito além de Platão, ele nos recorda da sentença do filósofo de Éfeso: “ Tu não deverás obedecer os limites da alma a tal ponto " (Fragmentos pré-socráticos, § 45).

A psiquê é abertura e, essa, sem limites. Será o medo da falta de limites que presidiu ao nascimento do sobre si mesmo da finitude?

\section{Notas}

1 Traduzido por Francisco Rüdiger do original francês publicado em Nietzsches-Studien Vol. 12: 80-110 (Berlim: Walter de Gruyter, 1983). Revisão de Juremir Machado da Silva. VPI e VPII referem-se, no texto, aos volumes da tradução francesa de Genevieve Bianquis (Paris, 1948, $26^{\circ}$ ed.) para Der Wille zur macht (A vontade de poder, 1935); WMà edição clássica dessa obra (1906); UWI ou UWII aos volumes de fragmentos póstumos reunidos sob o título Unschuld des Werdens da edição de bolso das obras completas do filósofo publicadas por Kröner Verlag; $K G W$ aos volumes da edição crítica das obras completas do filósofo organizada por Giorgio Colli e Mazzarino Montinari (Berlim: Walter de Gruyter, 1967ss); Nietzsche aos volumes da tradução francesa da obra do mesmo nome, escrita por Martin Heidegger (Paris: Gallimard, 1971).

2 Todavia excetuam-se dessa observação comentadores mais recentes, como W. Müller-Lauter.

3 Descartes: Meditation seconde (Ouevres philosophiues, edição Alquié, t. II, p. 419).

4 Critique de la Raison Pure (2ª ed., § 17, B 136).

5 Ainda que o uso dos termos traduzidos por nós como "instinto" e "pulsão" (Instinkt e Trieb) não corresponda a uma codificação rígida, Nietzsche - desde 0 nascimento da tragédia - designa por Trieb as forças "naturais" (pertencentes a physis mais geral e mais elementar: por exemplo, ao apolíneo e ao dionisíaco), reservando a palavra Instinkt aos que, em cada caso, têm um significado especial (instinto de conhecimento, instinto de apropriação) e, em, sentido mais limitado, a um sujeito particular (a um tipo humano determinado), isto é: mais socializado. Daí a nuance pejorativa associada à palavra Instinkt (a propósito ver a nota dos tradutores à edição de 0 nascimento $d a$ tragédia das obras completas).

\section{Heidegger: Hollzeweg (Trad. franc.: Gallimard, p. 196).}

7 Fazendo essa crítica nós lamentamos não ter tido conhecimento, antes do término deste trabalho, do notável e exaustivo estudo de Wolfgang Müller-Lauter, Nietzsche Leher vom Willen sur Macht, aparecido nos NietzscheStudiem, vol. 3 (1974): 1-60. Entretanto, devemos assinalar que concordamos em muito com as conclusões desse estudo, em particular no tocante a dois pontos 
precisos: 1) quando o autor mostra que não se pode atribuir à vontade de potência a unidade e universalidade de uma "essência" ou de um princípio supremo daqueles postulados pela metafísica tradicional (cf. a excelente crítica à posição heideggeriana, notadamente na nota 68 da página 23); a vontade de potência não existe de fato senão como uma pluralidade não-totalizável de forças engajadas em relações complexas e variáveis de oposição, subordinação, comando e obediência; 2) quando se mostra que o perspectivismo nietzscheano, como filosofia interpretativa, não pode ser reduzido a uma forma de subjetivismo (o que não significa que Nietzsche seja situável fora de o que Heidegger chama de metafísica da subjetividade) (vide nota 32 da p. 13 e pp. $43,44,59)$. Tomamos a liberdade de remeter 0 leitor a esse importante artigo, que fornece um impressionante leque de análises textuais nesse sentido e ainda traz uma sólida contribuição ao esclarecimento da problematização geral do "sujeito" em Nietzsche [ver trad. bras. de Oswaldo Giacoia: São Paulo, Annablume, 1997 nota do Org.]. 